\title{
THE PREDATION EFFICIENCY AND FEEDING PREFERENCE OF COCCINELLA SEPTEMPUNCTATA L. AND COCCINELLA UNDECIMPUNCTATA L. (COLEOPTERA: COCCINELLIDAE) ON SOME PREY SPECIES
}

\author{
A. A. E. Darwish \\ Plant Protection Department, Faculty of Agriculture, Damanhour University, Egypt
}

Received: Nov. 6,2018

Accepted: Nov. 27,2018

\begin{abstract}
To enhance the strategy of the biological control of the sucking insect pests using the Ladybird Beetles (Coleoptera: Coccinellidae), it is important to understand predator-prey interactions. Hence, the predation efficiency and preference of both larvae and adult of seven-spot ladybird, Coccinella septempunctata Linnaeus and the eleven-spot ladybird, Coccinella undecimpunctata Linnaeus on four prey species i.e., the green peach aphid, Myzus persicae (Sulzer), the cotton aphid, Aphis gossypii Glover, the bird cherry-oat aphid, Rhopalosiphum padi (Linnaeus) and onion thrips, Thrips tabaci Lindeman were evaluated under laboratory conditions at varying prey densities using a clear glass jars. There were significant differences between the consumed numbers of the four different species by the two different lady beetle species. The most consumed prey by $C$. septempunctata was the A. gossypii followed by $M$. persicae then $R$. padi and finally $T$. tabaci and these results were repeated in case of $C$. undecimpunctata with less feeding voracious. As the grubs of $C$. septempunctata and $C$. undecimpunctata developed from $1^{\text {st }}$ to $4^{\text {th }}$ larval instars, the consumption rates from aphid species and thrips increased. The consumption rates of M. persicae, A. gossypii, R. padi and T. tabaci significantly increased with the advancement in the larval stage of the two predators. The forth larval instar of $C$. septempunctata and $C$. undecimpunctata exhibited the highest predatory potential comparing to the first, second and third larval instars. The numbers of prey eaten by adult stage or different instars of larvae of the two predators increased significantly with prey density and reaching the maximum value when 150 preys were provided compared with 50 and 100 preys.
\end{abstract}

Key words: Biological control, Coccinella spp, Myzus persicae, Aphis gossypii, Rhopalosiphum padi, Thrips tabaci

\section{INTRODUCTION}

Piercing sucking insect pests (aphids, whiteflies, leafhoppers and thrips) are cosmopolitan pests attacking a wide variety of agricultural crops and causing either directly physical damage by sucking plant juice or indirectly damage as vector transmitting plant diseases (Carter, 1990). These insects widely distributed from tropical and subtropical areas into the temperate region (Kocourek, et al. 1994 and Pourian et al., 2009). The green peach aphid, Myzus persicae (Sulzer) (Hemiptera: Aphididae) one of the most important piercing sucking insect pests. It's attacking over four hundred plant species in more than fifty families (Weber, 1985). The cotton aphids, Aphis gossypii Glover is a polyphagous insect pest with a worldwide distribution (Inaizumi, 1980 and Kocourek, et al. 1994). The bird cherry-oat aphid, Rhopalosiphum padi (Linnaeus) is one of the fourteen aphid species considered of most agricultural importance worldwide (Blackman and Eastop, 2007). It is an important insect pest of cereals, causes severe damage in cereal producing countries (Stern, 1967; Kolbe, 1973 and Mallott and Davy, 1978). 
Over the past two decades the onion thrips, T. tabaci Lindeman has become a global pest of onion crop (Diaz-Montano et al., 2010). There is an urgent need to minimize the many serious problems in the environment components and biodiversity by exploring alternate measures than the intensive use of chemical synthetic insecticides such as biological control agents for management of these insects (Bellows, 2001). Predators like ladybirds can suppress the number of aphids and other piercing sucking insect pests consequently the predatory ladybird is generally considered the best candidate for bio-control of aphids and other piercing sucking insect pests (Dixon et al., 1995). The present study was conducted to compare the preference and predatory effect of Coccinella septempunctata and Coccinella. undecimpunctata on green peach aphids, M. persicae, cotton aphid, A. gossypii, the bird cherry-oat aphid, R. padi and the onion thrips, T. tabaci .

\section{MATERIALS AND METHODS}

The predation efficiency of adult stage and different larval instars of two ladybird beetles: $C$. septempunctata and C. undecimpunctata was studied under laboratory conditions on adults of each of Myzus persicae, Aphis gossypii, Rhopalosiphum padi and Thrips tabaci using a series of experiments using a clear glass jars $(20 \times 15 \mathrm{~cm})$ which were covered with a fine mesh for aeration and to prevent escaping of predators and preys. The experiments were done at $25^{\circ} \mathrm{C} \pm 2^{\circ} \mathrm{C}$ with a photoperiod of $14: 10$ (L:D) h.

\section{The prey species:}

The four preys which were used in this study (M. persicae, A. gossypii, $R$. padi and $T$. tabaci) were obtained from the culture maintained in the laboratory for experimentation. Each of M. persicae,
A. gossypii were provided in glass jars with fresh tomato leaves for feeding. While, R. padi was provided with fresh wheat seedlings and $T$. tabaci was provided with fresh leek leaves. After 24 hours the jars were checked for counting unconsumed aphids.

\section{The predators:}

Aphidophagous lady beetle species, which were known to be abundant and were found together feeding on aphid species and in the same habitats, were chosen for the present study. Each individual of the different instars and adults of the predators was provided with one of the following prey densities: 50 , 100 and 150 individuals/one glass jar. One day old for the different four instars and two-day-old for adult stage of the two predators were used for all experiments and these instars were starved for $12 \mathrm{~h}$ before use by placing them with the hosts on the jars.

The experiments were replicated five times for each instar of the two predators. The estimation of the predatory effect of the predators was based on the number of consumed individuals by the predator. Five more glass jars (for each prey density) were used as control. In these jars, there were the same numbers of preys per jar but in the absence of the predator.

The obtained results were subjected to the analysis of variance test (ANOVA) as randomized complete blocks design, and the least significant differences (LSD) at $5 \%$ level were determined using a computer program (Costat, 2008).

\section{RESULTS AND DISCUSSION}

Feeding potential of adult stage and different larval instars of the two ladybird beetles; $C$. septempunctata and $C$. undecimpunctata:

Results in (Tables 1-6) cleared that the feeding potential of adult stage and 
different larval instars of the two ladybird beetles; $C$. septempunctata and $C$. undecimpunctata under laboratory conditions was significantly dependent on prey species, prey density and predator-stage. There were significant differences between the consumed numbers of the four different species; $M$. persicae, A. gossypii, $R$. padi and $T$. tabaci by the two different lady beetle species. The most consumed prey by $C$. undecimpunctata was the cotton aphids, A. gossypii (with general consumption means of $13.16 \pm 1.51,17.56 \pm 1.73$ and 23.88 \pm 2.37 individual/day in 50, 100, 150 prey density) followed by $M$. persicae $(8.2 \pm 0.99,10.4 \pm 1.13$ and $13.48 \pm 1.5$ in 50 , 100, 150 prey density) then $R$. padi $(6.2 \pm 0.71,7.68 \pm 0.68$ and $10.92 \pm 1.05$ in 50 , 100, 150 prey density) and finally $T$. tabaci $(3.8 \pm 0.48,4.5 \pm 0.67$ and $6.35 \pm 0.85$ in $50,100,150$ prey density).

Table (1): Voracity (number of prey eaten \pm SE) of Coccinella undecimpunctata stages provided with $\mathbf{5 0}$ individuals of four preys under laboratory conditions

\begin{tabular}{|l|c|c|c|c|c|c|}
\hline \multicolumn{1}{|c|}{ Prey } & $\begin{array}{c}1^{\text {st }} \text { instar }_{\text {larvae }} \\
\text { R. padi }\end{array} 2^{2.4 \pm 0.51^{\text {ab }}}$ & $3.4 \pm 0.93^{\mathrm{b}}$ & $6.8 \pm 1.24^{\mathrm{c}}$ & $9.8 \pm 1.16^{\mathrm{c}}$ & $8.6 \pm 0.81^{\mathrm{bc}}$ & $6.2 \pm 0.71^{\mathrm{c}}$ \\
\hline A.gossypii & $3.2 \pm 0.58^{\mathrm{a}}$ & $7.6 \pm 0.93^{\mathrm{a}}$ & $15 \pm 1.41^{\mathrm{a}}$ & $21.2 \pm 1.98^{\mathrm{a}}$ & $18.8 \pm 1.93^{\mathrm{a}}$ & $13.16 \pm 1.51^{\mathrm{a}}$ \\
\hline M.persicae & $1.8 \pm 0.37^{\mathrm{b}}$ & $4 \pm 0.71^{\mathrm{b}}$ & $10.2 \pm 0.86^{\mathrm{b}}$ & $13.6 \pm 1.29^{\mathrm{b}}$ & $11.4 \pm 0.93^{\mathrm{b}}$ & $8.2 \pm 0.99^{\mathrm{b}}$ \\
\hline T. tabaci & $1.2 \pm 0.37^{\mathrm{b}}$ & $2.4 \pm 0.51^{\mathrm{b}}$ & $3.6 \pm 0.51^{\mathrm{d}}$ & $4.6 \pm 0.68^{\mathrm{d}}$ & $7.2 \pm 0.73^{\mathrm{c}}$ & $3.8 \pm 0.48^{\mathrm{d}}$ \\
\hline F values & 3.318 & 8.274 & 20.969 & 26.386 & 18.437 & 15.858 \\
\hline L.S.D. $5 \%$ & 1.4062 & 2.3606 & 3.194 & 4.0777 & 3.6101 & 2.8033 \\
\hline
\end{tabular}

Means in each column followed by different letters are significantly different at $P<0.05$

Table (2): Voracity (number of eaten prey \pm SE) of Coccinella undecimpunctata stages provided with 100 individuals of four preys under laboratory conditions

\begin{tabular}{|l|c|c|c|c|c|c|}
\hline \multicolumn{1}{|c|}{ Prey } & $\begin{array}{c}1^{\text {st }} \text { instar } \\
\text { larvae }\end{array}$ & $\begin{array}{c}2^{\text {nd }} \text { instar } \\
\text { larvae }\end{array}$ & $\begin{array}{c}3^{\text {rd }} \text { instar } \\
\text { larvae }\end{array}$ & $\begin{array}{c}4^{\text {th }} \text { instar } \\
\text { larvae }\end{array}$ & $\begin{array}{c}\text { Adult } \\
\text { stages }\end{array}$ & $\begin{array}{c}\text { General } \\
\text { mean }\end{array}$ \\
\hline R. padi & $3.6 \pm 0.51^{\mathrm{b}}$ & $5.2 \pm 0.86^{\mathrm{c}}$ & $8.4 \pm 0.51^{\mathrm{c}}$ & $11.4 \pm 1.17^{\mathrm{c}}$ & $9.8 \pm 1.02^{\mathrm{c}}$ & $7.68 \pm 0.68^{\mathrm{c}}$ \\
\hline A. gossypii & $6.2 \pm 1.07^{\mathrm{a}}$ & $10.8 \pm 0.86^{\mathrm{a}}$ & $21.2 \pm 2.35^{\mathrm{a}}$ & $24.6 \pm 2.2^{\mathrm{a}}$ & $25 \pm 2.17^{\mathrm{a}}$ & $17.56 \pm 1.73^{\mathrm{a}}$ \\
\hline M.persicae & $2.8 \pm 0.58^{\mathrm{b}}$ & $6.6 \pm 0.98^{\mathrm{b}}$ & $12 \pm 1.41^{\mathrm{b}}$ & $16.2 \pm 1.8^{\mathrm{b}}$ & $14.4 \pm 0.87^{\mathrm{b}}$ & $10.4 \pm 1.13^{\mathrm{b}}$ \\
\hline T. tabaci & $1.4 \pm 0.75^{\mathrm{c}}$ & $2.2 \pm 0.58^{\mathrm{d}}$ & $4.6 \pm 0.81^{\mathrm{d}}$ & $5.8 \pm 0.86^{\mathrm{d}}$ & $9.4 \pm 1.03^{\mathrm{c}}$ & $4.5 \pm 0.67^{\mathrm{d}}$ \\
\hline F values & 7.072 & 18.379 & 23.885 & 24.863 & 27.914 & 23.304 \\
\hline L.S.D. 5\% & $2.2733^{\mathrm{n}}$ & 2.4993 & 4.36 & 4.7874 & 4.1216 & 3.2022 \\
\hline
\end{tabular}

Means in each column followed by different are significantly different at $P<0.05$ (LSD test). 
Table (3): Voracity (number of eaten prey \pm SE) of Coccinella undecimpunctata stages provided with 150 individuals of four preys under laboratory conditions:

\begin{tabular}{|l|c|c|c|c|c|c|}
\hline \multicolumn{1}{|c|}{ Prey } & $\begin{array}{c}1^{\text {st }} \\
\text { larvae }\end{array}$ & $\begin{array}{c}2^{\text {nd }} \\
\text { instar } \\
\text { larvae }\end{array}$ & $\begin{array}{c}3^{\text {rd }} \text { instar } \\
\text { larvae }\end{array}$ & $\begin{array}{c}4^{\text {th }} \text { instar } \\
\text { larvae }\end{array}$ & $\begin{array}{c}\text { Adult } \\
\text { stages }\end{array}$ & $\begin{array}{c}\text { General } \\
\text { mean }\end{array}$ \\
\hline R. padi & $4.2 \pm 0.86^{\mathrm{b}}$ & $8 \pm 0.89^{\mathrm{b}}$ & $11.2 \pm 1.39^{\mathrm{c}}$ & $16.2 \pm 1.69^{\mathrm{c}}$ & $15 \pm 1.52^{\mathrm{bc}}$ & $10.92 \pm 1.05^{\mathrm{b}}$ \\
\hline A. gossypii & $9.6 \pm 1.29^{\mathrm{a}}$ & $14.4 \pm 1.4^{\mathrm{a}}$ & $24.8 \pm 2.65^{\mathrm{a}}$ & $36.6 \pm 2.25^{\mathrm{a}}$ & $34 \pm 3.7^{\mathrm{a}}$ & $23.88 \pm 2.37^{\mathrm{a}}$ \\
\hline M.persicae & $4 \pm 0.84^{\mathrm{b}}$ & $7.8 \pm 1.11^{\mathrm{b}}$ & $17.6 \pm 1.7^{\mathrm{b}}$ & $22 \pm 2.24^{\mathrm{b}}$ & $16 \pm 1.7^{\mathrm{b}}$ & $13.48 \pm 1.5^{\mathrm{b}}$ \\
\hline T. tabaci & $2.2 \pm 0.58^{\mathrm{b}}$ & $3.4 \pm 0.75^{\mathrm{c}}$ & $5.8 \pm 0.66^{\mathrm{d}}$ & $7.8 \pm 1.02^{\mathrm{d}}$ & $12.2 \pm 1.93^{\mathrm{c}}$ & $6.35 \pm 0.85^{\mathrm{c}}$ \\
\hline F values & 11.876 & 17.988 & 21.91 & 42.195 & 17.425 & 22.857 \\
\hline L.S.D. 5\% & 2.7802 & 3.201 & 5.2529 & 5.5967 & 7.1325 & 4.3736 \\
\hline
\end{tabular}

Means in each column followed by different letters are significantly different at $\mathrm{P}<0.05$

Table (4): Voracity (number of eaten prey \pm SE) of Coccinella septempunctata stages provided with $\mathbf{5 0}$ individuals of four preys under laboratory conditions.

\begin{tabular}{|l|c|c|c|c|c|c|}
\hline \multicolumn{1}{|c|}{ Prey } & $\begin{array}{c}1^{\text {st }} \text { instar } \\
\text { larvae }\end{array}$ & $\begin{array}{c}2^{\text {nd }} \text { instar } \\
\text { larvae }\end{array}$ & $\begin{array}{c}3^{\text {rd }} \text { instar } \\
\text { larvae }\end{array}$ & $\begin{array}{c}4^{\text {th }} \text { instar } \\
\text { larvae }\end{array}$ & $\begin{array}{c}\text { Adult } \\
\text { stages }\end{array}$ & $\begin{array}{c}\text { General } \\
\text { mean }\end{array}$ \\
\hline R. padi & $2.6 \pm 0.68^{\mathrm{b}}$ & $4 \pm 1.58^{\mathrm{b}}$ & $10.2 \pm 1.4^{\mathrm{c}}$ & $17 \pm 3.1^{\mathrm{c}}$ & $12 \pm 1.58^{\mathrm{c}}$ & $9.16 \pm 1.3^{\mathrm{c}}$ \\
\hline A. gossypii & $4.6 \pm 0.81^{\mathrm{ab}}$ & $11 \pm 1.14^{\mathrm{a}}$ & $25.6 \pm 3.93^{\mathrm{a}}$ & $40.6 \pm 5.24^{\mathrm{a}}$ & $32 \pm 5.17^{\mathrm{a}}$ & $22.76 \pm 3.12^{\mathrm{a}}$ \\
\hline M.persicae & $5.6 \pm 0.75^{\mathrm{a}}$ & $11.6 \pm 1.44^{\mathrm{a}}$ & $18.2 \pm 2.56^{\mathrm{b}}$ & $23.8 \pm 2.97^{\mathrm{b}}$ & $17.4 \pm 1.94^{\mathrm{b}}$ & $15.32 \pm 1.53^{\mathrm{b}}$ \\
\hline T. tabaci & $1.6 \pm 0.68^{\mathrm{b}}$ & $3 \pm 0.84^{\mathrm{b}}$ & $3.8 \pm 0.97^{\mathrm{d}}$ & $5 \pm 1.4^{\mathrm{d}}$ & $8.8 \pm 1.46^{\mathrm{d}}$ & $4.44 \pm 0.66^{\mathrm{c}}$ \\
\hline F values & 6.231 & 17.988 & 14.462 & 18.796 & 12.011 & 17.78 \\
\hline L.S.D. 5\% & 2.1928 & 3.201 & 7.477 & 10.3213 & 8.8809 & 5.2791 \\
\hline
\end{tabular}

Means in each column followed by different letters are significantly different at $\mathrm{P}<0.05$

Table (5): Voracity (number of eaten prey \pm SE) of Coccinella septempunctata stages provided with 100 individuals of four preys under laboratory conditions.

\begin{tabular}{|l|c|c|c|c|c|c|}
\hline \multicolumn{1}{|c|}{ Prey } & $\begin{array}{c}1^{\text {st }} \text { instar } \\
\text { larvae }\end{array}$ & $\begin{array}{c}2^{\text {nd }} \text { instar } \\
\text { larvae }\end{array}$ & $\begin{array}{c}3^{\text {rd }} \text { instar } \\
\text { larvae }\end{array}$ & $\begin{array}{c}4^{\text {th }} \text { instar } \\
\text { larvae }\end{array}$ & $\begin{array}{c}\text { Adult } \\
\text { stages }\end{array}$ & $\begin{array}{c}\text { General } \\
\text { mean }\end{array}$ \\
\hline R. padi & $4.2 \pm 0.37^{\mathrm{b}}$ & $8.4 \pm 0.82^{\mathrm{bc}}$ & $15.4 \pm 1.8^{\mathrm{c}}$ & $19.6 \pm 1.44^{\mathrm{c}}$ & $14.2 \pm 1.53^{\mathrm{c}}$ & $12.36 \pm 1.23^{\mathrm{c}}$ \\
\hline A. gossypii & $7.6 \pm 1.08^{\mathrm{a}}$ & $15.6 \pm 1.96^{\mathrm{a}}$ & $35.6 \pm 2.78^{\mathrm{a}}$ & $51.4 \pm 4.26^{\mathrm{a}}$ & $37.6 \pm 2.48^{\mathrm{a}}$ & $29.56 \pm 3.42^{\mathrm{a}}$ \\
\hline M.persicae & $5.4 \pm 0.87^{\mathrm{ab}}$ & $10.8 \pm 1.24^{\mathrm{b}}$ & $23 \pm 2.39^{\mathrm{b}}$ & $30.2 \pm 3.1^{\mathrm{b}}$ & $23.8 \pm 2.58^{\mathrm{b}}$ & $18.64 \pm 2.08^{\mathrm{b}}$ \\
\hline T. tabaci & $1.4 \pm 0.6^{\mathrm{c}}$ & $2.2 \pm 0.73^{\mathrm{c}}$ & $5.2 \pm 0.86^{\mathrm{d}}$ & $8.6 \pm 1.3^{\mathrm{d}}$ & $13.2 \pm 1.46^{\mathrm{d}}$ & $6.12 \pm 1^{\mathrm{d}}$ \\
\hline F values & 11.036 & 18.818 & 37.602 & 42.356 & 29.685 & 21.673 \\
\hline L.S.D. 5\% & 2.3319 & 3.851 & 6.5438 & 8.4024 & 6.2312 & 6.029 \\
\hline
\end{tabular}

Means in each column followed by different letters are significantly different at $\mathbf{P}<0.05$ 
Table (6): Voracity (number of eaten prey \pm SE) of Coccinella septempunctata stages provided with 150 individuals of four preys under laboratory conditions.

\begin{tabular}{|l|c|c|c|c|c|c|}
\hline \multicolumn{1}{|c|}{ Prey } & $\begin{array}{c}1^{\text {st }} \\
\text { lanstar }\end{array}$ & $\begin{array}{c}2^{\text {nd }} \text { instar } \\
\text { larvae }\end{array}$ & $\begin{array}{c}3^{\text {rd }} \text { instar } \\
\text { larvae }\end{array}$ & $\begin{array}{c}4^{\text {th }} \text { instar } \\
\text { larvae }\end{array}$ & $\begin{array}{c}\text { Adult } \\
\text { stages }\end{array}$ & $\begin{array}{c}\text { General } \\
\text { mean }\end{array}$ \\
\hline R. padi & $6.4 \pm 1.03^{\mathrm{b}}$ & $10 \pm 1.3^{\mathrm{b}}$ & $20.8 \pm 1.56^{\mathrm{b}}$ & $30.2 \pm 1.83^{\mathrm{b}}$ & $20 \pm 1.82^{\mathrm{bc}}$ & $17.48 \pm 1.84^{\mathrm{b}}$ \\
\hline A. gossypii & $9.4 \pm 1.17^{\mathrm{a}}$ & $19.6 \pm 1.81^{\mathrm{a}}$ & $42.6 \pm 2.79^{\mathrm{a}}$ & $55.4 \pm 3.16^{\mathrm{a}}$ & $38.4 \pm 2.46^{\mathrm{a}}$ & $33.08 \pm 3.5^{\mathrm{a}}$ \\
\hline M.persicae & $5.6 \pm 0.93^{\mathrm{b}}$ & $12 \pm 1.58^{\mathrm{b}}$ & $26.4 \pm 2.42^{\mathrm{b}}$ & $32.8 \pm 2.91^{\mathrm{b}}$ & $26.4 \pm 2.01^{\mathrm{b}}$ & $20.64 \pm 2.24^{\mathrm{b}}$ \\
\hline T. tabaci & $1.8 \pm 0.66^{\mathrm{c}}$ & $3 \pm 0.71^{\mathrm{c}}$ & $8.4 \pm 1.5^{\mathrm{c}}$ & $10.8 \pm 1.98^{\mathrm{c}}$ & $17.2 \pm 1.69^{\mathrm{c}}$ & $8.24 \pm 1.28^{\mathrm{c}}$ \\
\hline F values & 10.523 & 23.429 & 43.967 & 51.948 & 21.842 & 18.897 \\
\hline L.S.D. 5\% & 2.8912 & 4.2292 & 6.416 & 7.5962 & 6.0445 & 6.6283 \\
\hline
\end{tabular}

Means in each column followed by different letters are significantly different at $P<0.05$

The seven-spot ladybird, $C$. septempunctata behaved aggressively and their feeding was more voracious on these preys whereas the general means of consumed individuals of $A$. gossypii reach 22.76 $\pm 3.12, \quad 29.56 \pm 3.42$ and $33.08 \pm 3.5$ individuals/day. While these means recorded $15.32 \pm 1.53,18.64 \pm 2.08$ and $20.64 \pm 2.24$ individuals/day for $M$. persicae and $9.16 \pm 1.3,12.36 \pm 1.23$ and $17.48 \pm 1.84$ individuals/day for $R$. padi. The least preferable prey species for $C$. septempunctata was $T$. tabaci which recorded $4.44 \pm 0.66,6.12 \pm 1$ and $8.24 \pm 1.28$ individual/day in $50,100,150$ prey density, respectively.

Feeding potential of the two ladybird beetles predators was significantly dependent on prey species. Similar observations were recorded by Singh and Singh $(1993,1994)$ who reported that larvae of ladybird beetle (C. septempunctata) behaved aggressively and their feeding was voracious on aphids. Other studies reported that $C$. septempunctata is considered a potent predator for many aphid species (Hagen, 1987; Omkar and Srivastava, 2003 ; Kalushkov and Hodek, 2004). The differences in the numbers of prey individuals consumed by the two lady beetle species may be due to the size of prey (Finlayson, et al. 2010). The smallest insect that has been tested in this work was a cotton aphids followed by green peach aphids and finally the bird cherryoat aphid. Also the consumed numbers of preys may be affected by nutritional suitability of prey (Houck , 1991 and Roger et al. 2001), or chemical deterrence (Nishida and Fukami 1989).

Effect of larval instars of the two predators on prey consumption :

As the grubs of $C$. septempunctata and $C$. undecimpunctata developed from $1^{\text {st }}$ to $4^{\text {th }}$ larval instars, the mean consumption of individuals of its hosts from aphid species and thrips increased and its feeding potential was significantly prey and predator-stage dependent (Tables $\left.7 \quad \begin{array}{lll}7 & 8 & 8\end{array}\right)$. The consumption individuals of M. persicae, A. gossypii, $R$. padi and $T$. tabaci significantly increased with the advancement in the larval stage of the predator from instar to the following other. The forth larval instar of C. septempunctata and $C$. undecimpunctata exhibited the highest predatory potential comparing to the first, second and third larval instars. Obtained results (fourth instar fed voraciously) are in agreement with the results of Dixon et al. (1997), Dixon (2000), Singh and Singh (1993, 1994), 
Srivastiva et al. (1987) and Solangi, et al. (2007) who stated that the number of aphids consumed per day per larva varied from $1^{\text {st }}$ to $4^{\text {th }}$ instar and they reported that among all larval stages, $4^{\text {th }}$ instar was difficult to provide enough aphids to satisfy their voracious appetites. Ali and Rizvi (2007) and Arshad et al. (2017) found that adults of Coccinella septempunctata consumed more aphids than grubs.

Table (7): Means of consumed individuals of four prey species (R. padi, A. gossypii, $M$. persicae and $T$. tabaci) by $C$. undecimpunctata:

\begin{tabular}{|c|c|c|c|}
\hline \multirow{2}{*}{ Instars } & \multicolumn{3}{|c|}{ Prey density } \\
\cline { 2 - 4 } & 50 preys & 100 preys & 150 preys \\
\hline $1^{\text {st }}$ larvae & $2.15 \pm 0.27^{\mathrm{c}}$ & $3.5 \pm 0.53^{\mathrm{b}}$ & $5 \pm 0.76^{\mathrm{c}}$ \\
\hline $2^{\text {nd }}$ larvae & $4.35 \pm 0.58^{\mathrm{c}}$ & $6.2 \pm 0.81^{\mathrm{b}}$ & $8.4 \pm 1.02^{\mathrm{c}}$ \\
\hline $3^{\text {rd }}$ larvae & $8.9 \pm 1.09^{\mathrm{b}}$ & $11.55 \pm 1.56^{\mathrm{a}}$ & $14.85 \pm 1.82^{\mathrm{b}}$ \\
\hline $4^{\text {th }}$ larvae & $12.3 \pm 1.5^{\mathrm{a}}$ & $14.5 \pm 1.74^{\mathrm{a}}$ & $20.65 \pm 2.56^{\mathrm{a}}$ \\
\hline Adult & $11.5 \pm 1.17^{\mathrm{ab}}$ & $14.65 \pm 1.57^{\mathrm{a}}$ & $19.3 \pm 2.25^{\mathrm{ab}}$ \\
\hline F values & 18.754 & 14.190 & 13.947 \\
\hline L.S.D.5\% & 2.8806 & 3.7439 & 5.1092 \\
\hline
\end{tabular}

Means in each column followed by different letters are significantly different at $\mathbf{P}<0.05$.

Table (8): Means of consumed individuals of four prey species (R. padi, A. gossypii, $M$. persicae and $T$. tabaci) by C. septempunctata

\begin{tabular}{|c|c|c|c|}
\hline \multirow{2}{*}{ Instars } & \multicolumn{3}{|c|}{ Prey density } \\
\cline { 2 - 4 } & 50 preys & 100 preys & 150 preys \\
\hline $1^{\text {st }}$ larvae & $3.6 \pm 0.49^{\mathrm{c}}$ & $4.65 \pm 0.63^{\mathrm{c}}$ & $5.8 \pm .76^{\mathrm{c}}$ \\
\hline $2^{\text {nd }}$ larvae & $7.4 \pm 1.02^{\mathrm{c}}$ & $9.25 \pm 1.25^{\mathrm{c}}$ & $11.15 \pm 1.5^{\mathrm{c}}$ \\
\hline $3^{\text {rd }}$ larvae & $14.45 \pm 2.2^{\mathrm{b}}$ & $19.8 \pm 2.72^{\mathrm{b}}$ & $24.55 \pm 2.99^{\mathrm{b}}$ \\
\hline $4^{\text {th }}$ larvae & $21.6 \pm 3.35^{\mathrm{a}}$ & $27.45 \pm 3.85^{\mathrm{a}}$ & $32.3 \pm 3.81^{\mathrm{a}}$ \\
\hline Adult & $17.55 \pm 2.45^{\mathrm{ab}}$ & $22.2 \pm 2.44^{\mathrm{ab}}$ & $25.5 \pm 2.09^{\mathrm{ab}}$ \\
\hline F values & 11.586 & 14.779 & 19.674 \\
\hline L.S.D. $5 \%$ & 6.0677 & 6.8909 & 6.9491 \\
\hline
\end{tabular}

Means in each column followed by different letters are significantly different at $P<0.05$ 
Effect of prey density on the consumption rates of $C$. septempunctata and $C$. undecimpunctata:

The number of prey eaten by different instars of larvae of $C$. septempunctata and C. undecimpunctata and/or adult stage increased significantly with prey density (Fig. 1) reaching the maximum value when 150 preys were provided (for one jar).
At higher prey densities encounters rates are more frequent and consequently predators consume considerably more than the minimum required, this fact may be explain the increase in number of prey individuals consumed with increasing density. Obtained results are in agreement with published results in this manner (Ali, et al., 1994, Omkar and Pervez, 2004, Bahy El-Din, 2006 and Cabral, et al. 2009).

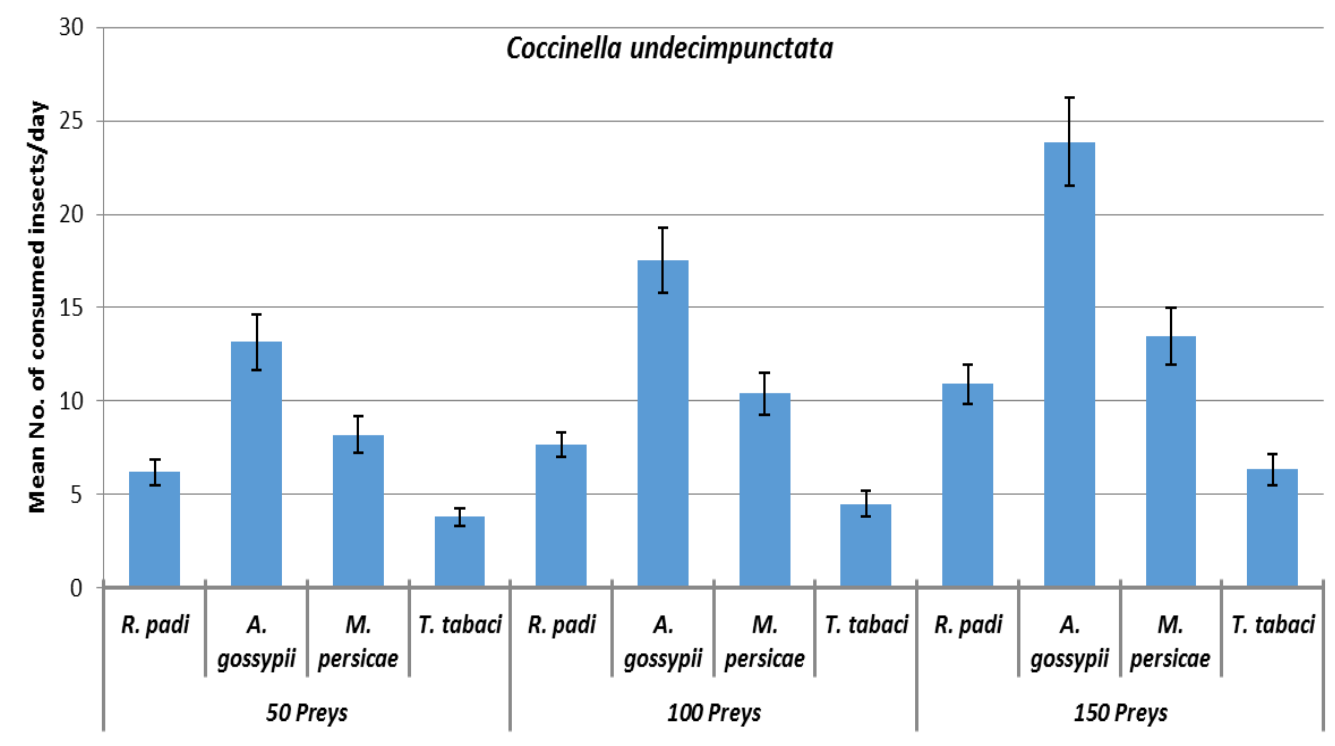

Prey density

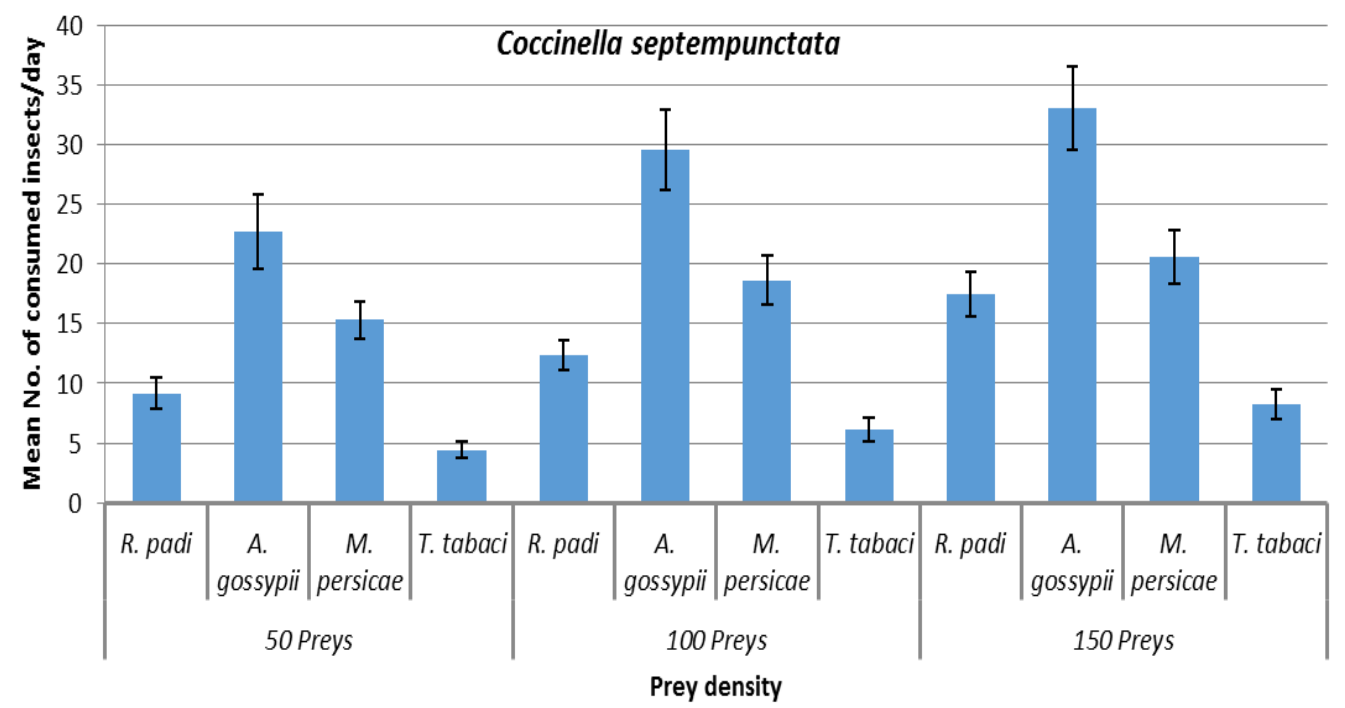

Fig. (1): Voracity (number of prey eaten \pm SE) of $C$. undecimpunctata and $C$. septempunctata stages fed on three densities (number of provided preys) of four prey species under laboratory conditions 


\section{Conclusion:}

In general, using of such natural enemies (C. septempunctata and $C$. undecimpunctata) in IPM programs can be useful with other safe alternative control methods. This will decrease the application of harmful pesticides and allow these natural enemies to do their role successfully in the field. Also, it was observed that $C$. septempunctata consumed large numbers of prey comparing to $C$. undecimpunctata in all trails in despite of the similarity in feeding behavior of both predators (devouring the entire body of the prey). Also, the obtained results reveal to the clear preference of the two predators for the aphid species than thrips tabaci.

\section{REFERENCES}

Ali, A. and P.Q. Rizvi (2007). Development and predatory performance of Coccinella septempunctata L. (Coleoptera: Coccinellidae) on different aphid species. Journal Biological Sciences 7: 1478-1483.

Ali, S.S., N. H. Rizvi, T. Hussain and S. S. H. Naqvi (1994). Searching and predatory efficiency of Coccinella septempuncata Linn under laboratory conditions on safflower aphid. Proc. Pak. Cong. Zool. Soc. of Pakistan, Govt. College, Lahore.Pp. 305-308.

Arshad, M., H. A. A. Khan, F. Hafeez, R. Sherazi and N. Iqbal (2017). Predatory Potential of Coccinella septempunctataL. against Four Aphid Species. Pakistan Journal of Zoology 49(2):623-627.

Bahy El-Din, I. A. E. (2006). Studies on the biology and feeding capacity of some coccinellid species. Unpublished M.Sc. Thesis, Fac. of Agric., Moshtohor Benha Univ., Egypt.

Bellows, T. S. (2001). Restoring population balance through natural enemy introductions. Biological Control 21: 199-205.

Blackman, R. L. and V. F. Eastop (2007). Taxonomic Issues, In: Aphids as Crop
Pests (Eds. H. F. van Emden and R. Harrington), 1-29. CABI, UK

Cabral, S., A. O. Soares and P. Garcia (2009). Predation by Coccinella undecimpunctata L. (Coleoptera: Coccinellidae) on Myzus persicae (Homoptera: Aphididae): Effect of prey density. Biological Control 50: 25-29.

Carter, F. L. (1990). Role of entomologists in producing quality cotton fiber. Brown, J. M., D. A. Richter (Eds.). Proc. Beltwide Cotton Conf.4-9 Jan. National Cotton Council, Memphis, TN, Las Vegas. NV : 171-173.

CoStat version 6.400 copyright (c) 19982008: Cohort Software. 798 Lighthouse Ave. PMB 320, Monterey, CA, USA.

Diaz-Montano, J., M. Fuchs, B.A. Nault and A.M. Shelton (2010). Evaluation of onion cultivars for resistance to onion thrips, Thrips tabaci (Thysanoptera: Thripidae) and Iris yellow spot virus. J. Econ. Entomol. 103 (3): 925-937.

Dixon, A. G. (2000). Insect predator-prey dynamics. Ladybird beetles and biological control. University of East Anglia. Cambridge Univ. Press, 257 pp.

Dixon, A. G., Hemptinne, J. L. and P. Kindlmann (1995). The ladybird fantasy-prospects and limits to their use in biocontrol of aphids. In: 75 years of phytopathological and resistance research at Aschersleben, Aschersleben (Germany), pp. 395-397.

Dixon, A. G., J. L. Hemptinne and P. Kindelmann (1997). Effectiveness of ladybirds as biological control agents: patterns and processes. Entomophaga 42, 71-83.

Finlayson, C., A. Alyokhin, S. Gross and E. Porter (2010). Differential consumption of four aphid species by four lady beetle species. J. of Insect Science 10:31

Hagen, K. S. (1987). Nutritional ecology of terrestrial insect predators. In: Nutritional Ecology of Insects, Mites, 
Spiders and Related Invertebrates. Ed. by Slansky, F.; Rodriguez, J. G. Jr. New York: John Wiley \& Sons, 533577.

Houck, M. A. (1991). Time and resource partitioning in Stethorus punctum (Coleoptera: Coccinellidae). Enviromental Entomology 20: 494-497. Inaizumi, M. (1980). Studies on the lifecycle and polymorphism of Aphis gossypii (Homoptera, Aphididae) [aphid]. Special Bulletin of the College of Agriculture-Utsunomiya University (Japan).

Kalushkov, P. and I. Hodek (2004). The effects of thirteen species of aphids on some life history parameters of the ladybird, Coccinella septempunctata. Biocontrol 49, 21-32.

Kocourek, F., J. Havelka, J. Berankova, Jarosiik and V. editors (1994). Effect of temperature on development rate and intrinsic rate of increase of Aphis gossypii reared on greenhouse cucumbers. Entomologia experimentalis et applicata.

Kolbe, W. (1973). Studies on the occurrence of cereal aphids and the effect of feeding damage on yields in relation to infestation density levels and control. Pflanzenschutz Nachrichten Bayer 26 (3): 396-410.

Mallott, P. G. and A. J. Davy (1978). Analysis of effects of the bird cherryoat aphid on the growth of barley: Unrestricted infestation. New phytologist, 80: 209-218.

Nishida, R. and H. Fukami (1989). Host plant iridoid-based chemical defense of an aphid, Acyrthosiphon nipponicus, against ladybird beetles. Journal of Chemical Ecology 15: 18371845.

Omkar, A. and S. Srivastava (2003). Influence of six aphid prey species on development and reproduction of a ladybird beetle Coccinella septempunctata. Biocontrol 48, 379393.
Omkar, A. and A. Pervez (2004). Functional and numerical responses of I (Col., Coccinellidae). Journal of Applied Entomology 128, 140-146.

Pourian, H.R., M. Mirab-balou, M. Alizadeh and S. Orosz (2009). Study on biology of onion thrips, Thrips tabaci Lindeman (Thysanoptera: Thripidae) on cucumber (var. Sultan) in laboratory conditions. J. Plant Prot. Res. 49 (4): 390-394.

Roger, C., D. Coderre, C. Vigneault and G. Boivin (2001). Prey discrimination by a generalist coccinellid predator: Effect of prey age or parasitism? Ecological Entomology 26: 163- 172.

Singh, D. and H. Singh (1993). Biology of ladybird beetle Coccinella septempunctata. Ann. Biol., 9: 250253.

Singh, H. S. and R. Singh (1994). Life fecundity table of Coccinella septempunctata $L$. predating on mustard aphid (Lipaphis erysimi Kalt.) under laboratory and field conditions. J. ent. Res., 18: 297-303.

Solangi, Bhai Khan, Mohammad Khan Lohar, G.H. Abro and M.A. Talpur (2007). Searching ability and feeding potential of larvae, 7-spotted beetle Coccinella septempunctata Linn. Under laboratory and field condition. Sarhad J. Agric. Vol. 23, No. 3, 705711.

Srivastiva, A.S., R. R. Katyar, K.D. Upadhay and S.V. Singh (1987). Studies on the food preference of Coccinella septempunctata L. (Coleoptra: Coccinellidae). Ind. J. Ent., 41: 551-552.

Stern, V. M. (1967). Control of aphids attacking barley and analysis of yield increases in the Imperial Valley, California. J. Econ. Ent. 60, 485.

Weber, G. (1985). Genetic variability in host plant adaptation of the green peach aphid, Myzus persicae. Entomologia Experimentalis et Applicata38 (1):49-56. 
Coccinella الكفاءة الافتراسية والتفضيل الغذائى لحشرتي أبوالعيد ذو السبع نقاط Coccinella وأبوالعيد ذو الاحدي عشر نقطة septempunctata undecimpunctata

$$
\text { عدنان عبدالفتاح السيد درويش }
$$

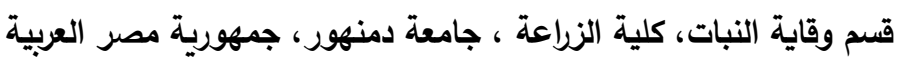

الملخص العببي

تم إختيار الكفاءة والتفضيل الافتراسي لكلا من اليرقات والحشرات البالغة للمفترسين أبوالعيد ذو السبع نقاط Coccinella septempunctata من حشرات مّن الخوخ الأخضر Myzus persicae ومّن القطن Aphis gossypii ومّن الثوفان Rhopalosiphum padi

$$
\text { الحشرية. }
$$

وقد وجد أن هناك فروق معنوية بين الافراد التي تم افتراسها للأنواع الاربعة بالنسبة للمفترسين الحشريين وكانت أكثر انواع الفرائس تفضيلا بالنسبة للمفترس أبو العيد ذو الاحدي عشر نقطة هي حشرة مّن القطن يليها حشرة مّن الخوخ

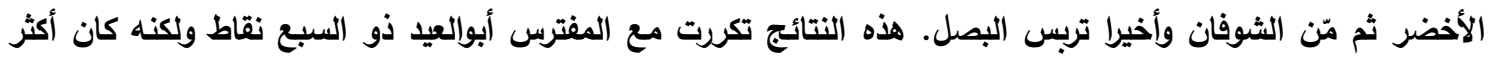
إفتراسا وشراهة في التغذية من المفترس أبو العيد ذو الاحدي عشر نقطة. وأيضا تم اختبار الكفاءة الإفتراسية للأعمار

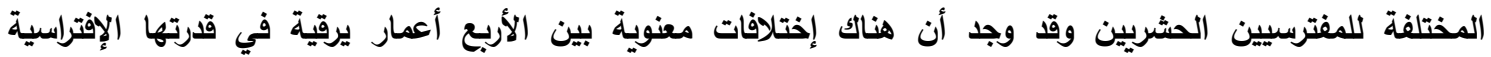

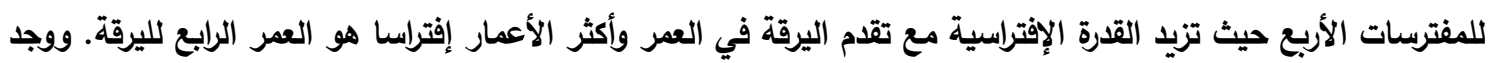

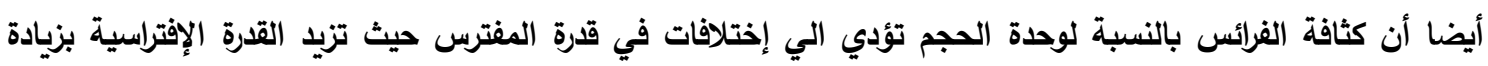
كثافة الفربسة.

$$
\begin{aligned}
& \text { أسماء السادة المحكمين } \\
& \text { معهد بحوث وقاية النبات - مركز البحوث الزراعية } \\
& \text { أ.د/ رضا عليوه سند إبراهيم }
\end{aligned}
$$

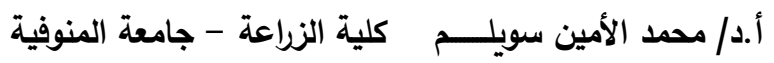


The predation efficiency and feeding preference of coccinella ...................

- 17 - 
